LAERE

MIDDEL

ODK

\title{
Lærernes valg og bruk av læremidler i spansk
}

Styrking av elevenes kultur- og demokratiforståelse i et faglig og allmenndannende perspektiv

Av Berit Grønn

Korrekt citering af denne artikel efter APA-systemet (American Psychological Association System, 7th Edition): Grønn, B. (2021). Lærernes valg og bruk av læremidler i spansk. Learning Tech - Tidsskrift for læremidler, didaktik og teknologi, (4), 120-150. DOI: 10.7146/lt.v6i9.124696 
I denne artikkelen belyses læreres valg av læremidler i spanskfaget på ungdomstrinnet (elever i alderen 13-15 år) i Norge. Det rettes søkelys mot undervisningssykluser som tar sikte på å styrke elevenes kultur- og demokratiforståelse: hvordan læremidler velges og benyttes for at elevene skal kunne trekke veksler på eget erfaringsog kunnskapsgrunnlag, og bygge videre på dette. Det empiriske materialet består av en kvalitativ intervjuundersøkelse gjennomført blant 17 spansklærere. Resultatene presenteres og analyseres i lys av læremidlenes didaktiske potensiale og tilrettelegging for elev- og kunnskapssentrering, tverrfaglige tilnærminger og fellesskapstenkning.

Funnene viser at læreboka ofte danner utgangspunkt for temavalg og mer helhetlige undervisningsopplegg, der lærerne trekker inn et større mangfold av læremidler. Dette i et forsøk på å gi elevene et nyansert bilde av spanskspråklige kulturer og flere innganger til demokratiforståelse. Det anvendes ulike verbale, nonverbale og audiovisuelle tilnærminger for å konkretisere abstrakte begreper, og for å stimulere til interaksjon i læringsprosessen.

My article focuses on teachers' selection of teaching and learning materials in Spanish as a Foreign Language in lower-secondary education (13-15 years) in Norway. I focus on materials suitable for strengthening students' cultural and democratic understanding and encouraging them to draw on personal experience and knowledge. My research draws on qualitative interviews with 17 Spanish teachers. My analyses rely on theories which specifically address the didactic potential of learning materials, learner- and knowledge-centred classroom environments, and interdisciplinary and communitycentred approaches. The course book guides the selection of teaching topics and is a point of departure to a broader selection of learning materials and lesson designs. In this way, teachers are able to provide students with a more nuanced picture of Hispanic cultures as well as more gateways to democratic understanding. They select different types of verbal, non-verbal and audio-visual materials in order to concretise abstract concepts, and promote student-student interactions. 


\title{
Lærernes valg og bruk av læremidler i spansk
}

\author{
Styrking av elevenes kultur-og \\ demokratiforståelse i et faglig og \\ allmenndannende perspektiv
}

\section{Indledning - undersøkelsens bakgrunn og formål}

I denne artikkelen presenteres og diskuteres noen eksempler på hva spansklærere i Norge legger vekt på når de velger ut og benytter læremidler i undervisningssykluser, der målet er å styrke elevenes kultur- og demokratiforståelse, både i et fagspesifikt og et bredere allmenndannende perspektiv. Hovedfokus er valg og bruk av læremidler i spanskfaget og i tverrfaglige prosjekter, der spansk er involvert, på ungdomsskolen (8.-10. trinn), det vil si elever i aldersgruppen 13-15 år. Eksemplene er resultat av en kvalitativ intervjuundersøkelse blant totalt 17 spansklærere på ungdomstrinnet, først i form av en pilotundersøkelse blant tre lærere våren 2018, og deretter i form av mer omfattende og systematiske intervjuer blant 14, lærere i desember 2020 og januar 2021. Det rettes spesielt søkelys på de deltakende lærernes beskrivelser og refleksjoner over egen praksisutøvelse, der de forteller hvilke faglige og didaktiske vurderinger de gjør med hensyn til valg av læremidler til sin spanskundervisning og hvilke erfaringer de har gjort seg med disse læremidlene.

Ideen til denne forskningsundersøkelsen ble til i 2018 i forbindelse med revisjonen av den generelle delen av læreplanen (Kirke-, utdannings- og forskningsdepartementet, 1993) og fagplanene i læreplanreformen Kunnskapsløftet (LKo6), som ble innført i 2006 (Utdannings- og forskningsdepartementet, 2005). I 2018 var den generelle delen av læreplanverket, som beskriver skolens allmendannende oppdrag og verdigrunnlag, ferdig revidert med den nye tittelen Overordnet del - verdier og prinsipper i grunnopploeringen (Kunnskapsdepartementet, 2017a). Der understrekes det at skolens kunnskapsgrunnlag skal tilrettelegge for å danne hele mennesket og gjøre alle elever i stand til å delta i demokratiske prosesser 
(Bjørnsrud \& Nilsen, 2021, s. 68; 75). Det fastslås også at demokrati og medborgerskap skal inngå som ett av tre tverrfaglige temaer i det fornyede læreplanverket (Kunnskapsdepartementet, 2017a, s. 38). Ifølge Janicke Heldal Stray (2011, s. 11) er en av grunnene til at demokratisk medborgerskap har fått økt oppmerksomet de senere år, både hos nasjonale utdanningsmyndigheter og internasjonale institusjoner og organisasjoner, som Europarådet, EU og OECD, at dagens samfunn er flerkulturelt og pluralistisk.

I 2017 lanserte Kunnskapsdepartementet en egen strategi med tittelen Strategifor fagfonyelsen, som hadde som mål å gjøre fagene i Kunnskapsløftet mer relevante for framtiden (Kunnskapsdepartementet, 2017b). Denne strategien bygde blant annet på Stortingsmelding nr. 28 (2015-2016) Fag - Fordypning Forståelse. En fornyelse av Kunnskapsløftet, som stadfester viktigheten av at elevene lærer om temaer fra forskjellige faglige perspektiver og utvikler evnen til å se og forstå sammenhenger (St. Meld. nr. 28 (2016), s. 33; 38). Viktige målsetninger var å bygge videre på det eksisterende læreplanverkets hovedprinsipper, herunder utvikling av elevenes grunnleggende ferdigheter, som å lese, skrive og uttrykke seg muntlig. Samtidig skulle dybdelæring, forståelse og tverrfaglige tilnærminger gis større betydning enn tidligere (Kunnskapsdepartementet, 2017b, s. 5).

Allmenndannende utdanningsmål, som utvikling av en bred kulturforståelse og demokratikompetanse, representer imidlertid ikke noe nytt, men er en aktualisering og forsterkning av tidligere skolepolitiske målsetninger: Læreplanverkets tidligere generelle del fremhever at elevene skal tilegne seg kunnskaper om demokrati og vår felles kulturarv, samtidig som de skal lære å utvise åpenhet og respekt for andre mennsker og kulturer. Det fremheves også at elevenes evne til finne sammehenger og oppnå forståelse utvikles ved at det nye forstås ut fra det kjente, og ved at egne erfaringer knyttes til konkret kunnskap og helhetlige referanserammer (Kirke-, utdannings- og forskningsdepartement, 1993).

Ett hovedmål i Loreplan ifremmedspråk, som ble innført i 2006 (LKo6), er at elevenes demokratiske engasjement og medborgerskap skal styrkes gjennom økt innsikt i egne og andre menneskers leve- og tenkemåter og kulturelle uttrykksformer (Utdanningsdirektoratet, 2006, s. 2). Ideen om at kjennskap til og møte med andre kulturer kan bidra til demokratisk dannelse videreføres og tydeliggjøres i revidert Loereplan ifremmedspråk (Utdanningsdirektoratet, 2019), som implementeres gradvis fra og med august 2020 til og med juni 2023. I læreplanen inngår nettopp demokrati og medborgerskap som overordnet tverrfaglig tema, og interkulturell kompetanse er ett av fire kjerneelementer i faget 
(Utdanningsdirektoratet, 2019, s. 2-3). Dette legger noen generelle føringer for hva faget skal inneholde, samtidig som læreplanen gir læreren/lærerkollegiet handlingsrom til å bestemme hvordan kompetansemålene skal konkretiseres i undervisningen.

I lys av spanskfagets kultur- og demokratifremmende rolle, $\emptyset n s k e t$ jeg derfor å skaffe meg mer kunnskap om hvilke temaer det arbeides med i undervisningen i overgangen fra den tidligere til den nye læreplanen, hvilke læremidler som benyttes i tilknytning til disse, og hvorfor. Jeg formulerte derfor følgende tre forskningsspørsmål:

\section{Hva vektlegger lærerne når de velger ut læremidler for undervisningssykluser i spansk, der hensikten er å styrke elevenes kultur- og demokratiforståelse, og hvorfor?}

\section{Hva slags arbeidsmåter legger lærerne opp til i tilknytning til de valgte læremidlene, og på hvilke måter gir disse mulighet til å bygge videre på elevenes kunnskaps- og erfaringsgrunnlag?}

\section{Hvilke erfaringer har lærerne gjort seg med bruken av de valgte læremidlene?}

Formålet med undersøkelsen var altså å danne meg et bilde av hvorvidt og på hvilke måter de valgte læremidlene brukes for å nå fagspesifikke og allmenndannende mål. For å søke svar på mine forskningsspørsmål valgte jeg en kvalitativ og eksplorativ tilnærming, som ble realisert i form av lærerintervjuer. Resultatene vil dermed vise et lite utsnitt av de deltakende lærernes didaktiske overveielser når de velger læremidler i spansk og deres erfaringer med bruken av dem så langt. Dette kan gi et diskusjonsgrunnlag for hvorvidt og på hvilke måter de læremidler som benyttes, bidrar til å øke elevenes kultur- og demokratiforståelse. Resultatene kan også bidra til å skissere noen områder og enkeltfenomener det bør forskes videre på.

Jeg vil først kort presentere spanskfagets plass i det norske skolesystemet og læremiddelforskning i tilnytning til spansk på ungdomstrinnet i Norge. Deretter legger jeg fram det teoretiske perspektivet jeg baserer meg på, og datainnhentingsmetoden jeg anvendte. Så følger en presentasjon og diskusjon av resultatene fra undersøkelsen. 


\section{Spansk som fremmedspråksfag på ungdomsskolen i Norge}

I det norske skolesystemet inngår fremmedspråk som gjennomgående fag på ungdomstrinnet og i videregående opplæring. Lcereplan i fremmedspråk er inndelt i tre nivåer: nivå I, II og III (Utdanningsdirektoratet 2006; 2019). Dette innebærer at elevene, når de starter på 8. trinn (13 år) kan velge mellom fremmedspråk som fransk, spansk, tysk eller et annet fremmedspråk, avhengig av hvilke(t) språk skolen tilbyr. Alternativt kan elever som ikke ønsker å lære et fremmedspråk, velge arbeidslivsfag eller fordyping i engelsk, norsk, samisk eller matematikk. Med innføringen av Kunnskapsløftet i 2006 gjorde spansk sitt inntog i fremmedspråksfaget på ungdomstrinnet. Siden den gang har spansk vært det mest valgte av fremmedspråkene, med tysk og fransk på henholdsvis andre og tredje plass (Nasjonalt senter for fremmedspråk i opplæringen, 2021, s. 2; Doetjes, 2018, s. 31; $38)$.

På ungdomstrinnet tilbys fremmedspråk nivå I, og antall undervisningstimer utgjør totalt 222 timer (Utdanningsdirektoratet, 2006, s. 3). Hvordan disse timene fordeles timeplanmessig bestemmes på lokalt nivå. Skoleåret 2020-2021 tas den nye Løereplan i fremmedspråk (LK20) (Utdanningsdirektoratet, 2019) i bruk på 8. og 9. trinn, mens 10. trinn følger den tidligere Loereplan i fremmedspråk (LKo6) (Utdanningsdirektoratet, 2006). Både ny og tidligre læreplan bygger i stor grad på samme prinsipper og praksis for språkopplæring som Det felles europeiske rammeverket for språk, som vektlegger en handlingsorientert og praktisk-kommunikativ tilnærming, flerpråklighet og det flerkulturelle samfunn (Utdanningsdirektoratet, 2011, s. 10-12; Council of Europe, 2020, s. 123-124).

\section{Tidligere undersøkelser}

Studier som ble gjennomført innen fremmedspråksdidaktikk tidlig på 200o-tallet, viser at i den norske skolekonteksten spiller læreboka en relativt sentral rolle, se blant annet Kåre Solfjelds intervjuundersøkelse blant totalt 15 fransk-, spansk-, tysk- og finsklærere på ungdomstrinnet (Solfjeld, 2007, s. 4; 12).

Det er gjennomført få studier om læremidler i spansk på ungdomstrinnet i Norge. I sin doktorgradavhandling fra 2012 foretok Liv Eide en innholds- og tekstanalytisk undersøkelse av lærebøker i spansk myntet på elever på ungdomstrinnet og i videregående skole (Eide, 2012). Hun fant at lærebøkene, med sine forsøk på å appellere til norske ungdommer, preges av et populærkulturelt innhold, og at de gir et lite nyansert bilde av den spanskspråklige verden. 
I artikkel rundt samme tema viser Eide (2013, s. 7-8). hvordan temaer som musikk, dans, mat, idrett, ferie og fritid utpeker seg i tekstbøker som er beregnet på spansk nivå I. Framtredende er også enkle faktatekster om geografi, klima, styreform, befolkningstall, turisme og lignende i ulike spansktalende land. Hun diskuterer hvorvidt disse lærebokstekstene utfordrer elevenes eksisterende forestillinger om den spanskspråklige verden, og mener at de i liten grad oppfyller formålet om at fremmedspråksfaget skal være et kulturog danningsfag (Eide, 2013, s. 7-8).

I sin doktorgradsavhanding om praktisk tilnærming i fremmedspråksfaget (Heimark, 2013), fant Gunn-Elin Heimark at fransk-, spansk- og tysklærere på ungdomstrinnet legger stor vekt på kunnskapsformidling i kulturkomponenten: De er opptatt av å øke elevenes kunnskaper om særlig mat og musikk, men også film, historie, nyheter, geografi og levemåter, samt at elevene lærer høflighetsfraser, skikk og bruk. Et fåtall av respondentene i studien fremhever viktigheten av å velge kulturspesifikke temaer som er interessante for ungdomsskoleelever (Heimark, 2013, s. 185).

I en dansk skolekontekst, viser Susana S. Fernández (2019, s. 86-87) til forskning på spanskundervisningen på gymnasnivå, der det framkommer at lærerne, til tross for gode intensjoner og bevissthet om viktigheten av et interkulturelt perspektiv, ofte opplever at de mangler tid og ressurser til implementering av denne type undervisning. Andre utfordringer i tilknytning til arbeidet med den kulturelle dimensjonen i faget, er mangel på relevant undervisningsmateriale, samt at elevenes begrensede språkkompetanse gjør det vanskelig å stimulere til adekvate refleksjons- og bevisstgjøringsprosesser (Fernandez, 2019, s. 86-87).

\section{Teoretisk ramme og begrepsavklaringer}

\section{Læremidler som didaktisk kategori}

Læremidler kan understøtte tilretteleggelsen for undervisning på forskjellige vis. I denne studien tar jeg utgangspunkt i Jens Jørgen Hansen (2012a, s. 16) sin inndeling av læremidler i fire hovedkategorier: semantiske loeremidler, didaktiske loeremidler, loeringsredskaper og kommunikasjonsmedier. Mens semantiske og didaktiske læremidler er meningsbærende i seg selv, fungerer læringsredskaper, eksempelvis et tekstbehandlingsprogram eller et tankekart, som verktøy og hjelpemiddel for å lette elevenes læreprosesser (Hansen, 2012a, s. 21-22). 
Semantiske læremidler, som nyhetsartikler og filmer, er produsert for ulike formål og med tanke på mottakere utenom skolekonteksten. Det kreves derfor en didaktisk tilrettelegging fra lærerens side når denne type læremidler skal anvendes i en skolekontekst (Hansen, 2012b, s. 51; Hansen \& Gissel, 2017, s. 125). Didaktiske læremidler, på sin side, er laget for et undervisningsformål, det være seg en lærebok (papir- eller nettbasert) eller faglige læringsspill (Hansen, 2012a, s. 24-25).

Kommunikasjonsmedier er redskaper og medier som muliggjør undervisningen. På den ene side, fungerer de som støtte for lærerens formidling av lærestoffet, og, på den annen side, som støtte for eleven til å kunne tilegne seg og forstå lærestoffet. Hansen (2012a, s. 23) skiller mellom kontaktmedier og forståelsesmedier: 1) kontaktmedier betyr at eleven kommer i kontakt med et lærestoff, for eksempel gjennom å lytte til lærerens formidling, eller ved å lese en tekst i læreboka, og 2) forståelsesmedier kan bidra til at eleven forstår og bearbeider lærestoffet bedre. Det kan for eksempel være måten tekstinnholdet er presentert på (lett/vanskelig tilgjengelig) og bruk av ulike presentasjonsformer, som tekst, bilde, lyd, kunstuttrykk og så videre. Forståelsesmedier innbefatter også ulike måter eleven interagerer med lærestoffet på, for eksempel å lese, undersøke, produsere, presentere og diskutere (Hansen, 2012a, s. 23).

I et språklæringsperspektiv er digitale verktøy ikke bare en støtte for språklæringen, men en integrert del av en helhetlig kontekst, der språk eksisterer og tas i bruk, både i skole- og arbeidsliv, hverdag og fritid (Lantolf \& Poehner, 2014, s. 40). Sett fra et interkulturelt perspektiv, gir digitale løsninger elevene muligheter til å stifte bekjentskap med ulike typer kulturelle uttrykksformer og til å skape kontakt og sosial interaksjon i det virtuelle rom, på tvers av landegrenser og kulturelle skiller, noe som igjen kan bidra til å styrke gjensidig respekt og forståelse (Soriano Ayala, 2013, s. 91).

\section{Læremiddelets didaktiske potensiale}

Man opererer med tre faser i læremiddelets didaktiske potensiale: potensielt, aktualisert og realisert. Læremiddelet blir betraktet som potensielt når det fungerer som hjelp til å oppfylle opplæringens allmenne og fagspesifikke mål. Det kan for eksempel være at man som lærer ser en musikkvideo og tenker at denne egner seg godt for anvendelse i en bestemt undervisningssituasjon. Man begynner da å planlegge hvordan den aktuelle videoen skal integreres i undervisningen. Med andre ord, et læremiddel er potensielt didaktisk så lenge det utgjør en del av planleggingsfasen og ennå ikke er blitt tatt i bruk av læreren eller elevene (Hansen \& Gissel, 2017, s. 125-26). 
Det aktualiserte potensialet manifesterer seg når læremiddelet tas i bruk i den konkrete undervisnings- og læringssituasjonen. Læreren sørger for at det didaktiske designet, som vil kunne bidra til at elevene lærer noe nytt, er på plass. Gjennom deltakelse i faglige og sosiale prosesser, for eksempel ved at elevene ser og diskuterer musikkvideoens innhold og form, vil både læreren og elevene kunne danne seg en formening om hva slags lærdom man kan trekke ut av arbeidet med dette læremiddelet og dets kvaliteter (Hansen \& Gissel, 2017, s. 126).

Å transformere et semantisk læremiddel, eksempelvis en nyhetsartikkel, til et didaktisk design, krever mer kreativitet fra lærerens side til forskjell fra didaktiske læremidler, der lærebokforfatteren/-produsenten allerede har tenkt igjennom og tatt mange av de didaktiske valgene (Hansen \& Gissel, 2017, s. 124125). I den forbindelse skiller Dagrun Skjelbred (2019, s. 74) mellom to ulike roller: loeremiddelloereren, og klasseromsloereren. En lærebok formidler et bestemt faginnhold som eleven skal tilegne seg, den inneholder bestemte oppgaver som eleven skal utføre, og så videre (Skjelbred, 2019, s. 74). I planleggingen og gjennomføringen av undervisningen fungerer dermed læreboka som en slags parallellærer som klasseromslæreren må samarbeide med, og det er viktig at klasseromslæreren er sin rolle bevisst og i stand til å ta selvstendige og profesjonelle valg i anvendelsen av læreboka (Hansen, 2010, s. 95).

\section{Elevsentrering, kunnskapssentrering og fellesskapssentrering}

En rekke faktorer har betydning for elevens læring, deiblant i hvor stor grad og hvordan undervisningen er kunnskapssentrert, elevsentrert og fellesskapssentrert. Dette påvirker i sin tur lærerens valg av lærestoff og læremidler (Brandsford, Brown \& Cocking i Munthe, 2020, s. 221).

Elevsentrering handler om at man i undervisningsplanleggingen tar utgangspunkt i elevenes tidligere læring og forståelse, deres hittil ervervede begrepsapparat, antakelser, verdier og interesser, med det for øye å bygge videre på deres kunnskaper og ferdigheter, og skape engasjement (Brandsford, Brown \& Cocking i Munthe, 2020, s. 221). Kunnskapssentrering omhandler det mest essensielle av kunnskaper og ferdigheter som elevene skal tilegne seg for å nå det aktuelle læringsmålet, samt hvilken relevans disse har i elevens liv i et nåtidig og fremtidig perspektiv (Brandsford, Brown \& Cocking i Munthe, 2020, s. 221). Ifølge Halvor Bjørnsrud og Sven Nilsen (2021, s. 70-73), er det særlig tre kunnskapssyn og -tradisjoner som kommer til syne i de overordnede føringene i læreplanverket Kunnskapsløftet: 1) praktisk arbeid og læring gjennom erfaring; 2) teoretisk kunnskap og 3) vår kulturelle tradisjon. Språkfagene forbindes spesielt med teoretisk kunnskap og vår kulturelle tradisjon. Sistnevnte knyttes til 
innlevelsesevne og uttrykkskraft (Bjørnsrud \& Nilsen, 2021, s. 70).

Når det gjelder kulturkomponenten i engelsk- og

fremmedspråksfagene, var det fram til 1980-tallet et herskende syn at elevene skulle tilegne seg teoretiske og faktaorienterte kunnskaper om kulturelle og samfunnsmessige aspekter, som politiske og sosiale vilkår, i målspråklandene (Risager, 2018). Siden 1980-tallet har det vært en dreining mot et mer utvidet kủnnskapssyn, hvor man trekker inn mer affektive sider ved læringen, som hver enkelt elevs/ elevgruppens tidligere erfaringer, følelser, holdninger og engasjement. I forbindelse med kulturrelaterte temaer, bør følgelig lærmidlene som anvendes bestå av ulike teksttyper og tekstinnhold som gir mening for elevene (Tomlinson, 2012, s. 346). Dette kan for eksempel være musikk, sangtekster, litteratur og andre former for kunstuttrykk, som gir elevene mulighet til å respondere på dem fra sitt eget ståsted (Tomlinson, 2012, s. 346; 348). Dermed er det snakk om tilegnelse av ulike former for kunnskap, ikke bare eksplisitt, faktaorientert kunnskap, men også hvordan kunnskapen organiseres gjennom bruk av ulike konsepter og tankesystemer (som binære par nord/sør, vi/dem o.l.) og sunn fornuft (Billing i Risager, 2018).

Fellesskapssentrering omfatter både lærer-elev-relasjoner og elev-elev-relasjoner, der det å tilrettelegge for et godt læringsmiljø tillegges stor vekt, blant annet med tanke på utvikling av elevenes samarbeids- og deltakelseskompetanse. Fellesskapssentreringen sees også i et videre perspektiv, i en større skolekontekst og med henblikk på sammenhengen mellom opplæringen og samfunnet omkring (Billing i Risager, 2018, s. 230-231). Et fremmedspråksfag som spansk kan bidra til å øke elevenes kunnskaper om kultur og kulturelle manifestasjoner i den spansktalende verden, både i en lokal og global sammenheng. I så henseende er det i fremmedspråksundervisningen viktig hvilket kultursyn man vil vektlegge, og hvordan tekst-, lyd- og billedmaterialet som man bruker, er med på å understøtte dette kultursynet (Risager, 2018).

\section{Demokratisk danning}

Marit Ulvik og Herner Sæverot (2020, s. 37) fremhever at danningsfremmende undervisning er en dynamisk prosess mellom individet og den aktuelle kulturen. De tar blant annet utgangspunkt i en sentral tanke hos Wolfgang Klafki om at undervisningen bør knyttes til samtidens nøkkelproblemer. Disse endres med historiens gang, og må stadig redefineres (Klafki i Ulvik \& Sæverot, 2020, s. 3738). Dannelse skjer altså i et samspill mellom innhold og subjekt. I utdanningssammenheng er det eleven som er subjektet: Eleven åpner 
seg for verden, og verden åpner seg for den enkelte elev (Klafki, 2001, s. 192-193). I dagens digitaliserte og globaliserte samfunn er de unge utsatt for en enorm informasjonsstrøm og en rekke kommunikasjonsmuligheter. Ulvik og Sæverot (2020, s. 42) understreker derfor viktigheten av at "... innholdet som skolen presenterer skjer i dialog med elevene, nettopp for å gi rom for deres erfaringer og respons." Kunnskapene som elevene tilegner seg i den formelle opplæringen er ikke bare faktaorientert, men også av subjektiv og intersubjektiv art: Likeså viktig som å oppnå forståelse av et bestemt saksforhold, er det å lære å forstå seg selv - sine egne ønsker, drømmer og forventninger - og andres måter å tenke og føle om verden på. Slik stimuleres elevene til å bli autonome, frie og personlig og sosialt ansvarlige (von Oettingen, 2017, s. 208).

Stray (2011, s. 14) deler demokratisk medborgerskap i to kategorier, status og rolle. Mens status refererer til statsborgerskap og er en juridisk betegnelse, refererer demokratisk medborgerskap som rolle til personen som deltaker i et politisk felleskap. I

opplæringssammenheng står en aktiv deltakelsesdimensjon sentralt: Demokratisk medborgerskap kan forstås som det å lære å leve sammen i et demokrati (Stray, 2011, s. 45). Dette innebærer blant annet at elevene skal "... tilegne seg kompetanse og kunnskap som de kan bruke i samfunnet som samfunnsdeltakere, og at de skal få prøve ut sine meninger og forestillinger" (Stray, 2011, s. 45). Dette innebærer blant annet at læreren styrer undervisningen i retning av møtesituasjoner (Ulvik \& Sæverot, 2020, s. 44), for eksempel ved at frivillige aktører i nærmiljøet inviteres til undervisningen, eller at elevene samarbeider i felles prosjekter på tvers av skoletrinn/skoler.

\section{Metode}

\section{Utvalget av informanter og datainnhentingsmetode}

I utvelgelsen av informanter, både i pilotundersøkelsen i mai 2018 og i hovedundersøkelsen i desember 2020 og januar 2021, la jeg opp til en såkalt purposeful selection of participants (jf. Creswell \& Creswell, 2018, s. 185). Som didaktiker i spansk har jeg en stor og bred kontaktflate med spansklærere i Norge. Jeg sendte derfor en forespørsel om deltakelse i undersøkelsene via e-post til spansklærere jeg visste underviste på ungdomstrinnet, deriblant noen med lang undervisningserfaring. Dette for å sikre at jeg hadde noen nøkkelinformanter, da jeg antok at de satt på mye informasjon og kunnskap (jf. Krumsvik, 2019, s. 159). I e-posten la jeg ved et informasjonsskriv om formålet med undersøkelsen, anonymitet og konfidensialitet. Så å si alle som jeg henvendte meg til, takket 
umiddelbart ja til å delta i undersøkelsen.

Jeg valge individuelle, kvalitative intervjuer som

datainnhentingsmetode, da denne metoden egner seg godt for å få økt innsikt i hver enkelt lærers beskrivelser og subjektive forståelse av sine pedagogiske handlinger. Med andre ord, jeg søkte intervjupersonenes egne beretninger om deres praksisutøvelse, hvilke intersjoner de hadde, hva de måtte ta stilling til, og hvilke handlinger som var blitt realisert (jf. von Oettingen, 2018, s. 39). Studieobjektet var altså informantenes ord, det de sa at de hadde gjort (jf. Krumsvik, 2019, s. 153).

\section{Design og gjennomføring av hovedundersøkelsen}

I den påfølgende, mer omfattende undersøkelsen, som ble gjennomført via Skype 1 1⁄2 år senere, la jeg opp intervjuene på samme måte og med samme varighet som i pilotundersøkelsen (se intervjuguide ovenfor). 14, lærere fra ungdomstrinnet deltok. Informantene svarte i form av å gjenfortelle planleggingen og gjennomføringen av undervisningssykluser. Framstillingene deres viste typiske narrative trekk, som vektlegging av kronologien i hendeleseforløpet, eksempelvis gjennom ytringer som "Elevene nevnte en sang [...], så tenkte jeg at sangteksten kunne brukes til å [...], så jeg lagde et opplegg der elevene skulle [...]"). Tidvis stoppet de opp for å gi inngående beskrivelser og reflektere over egne didaktiske valg.

En svakhet med å stille såpass åpne spørsmål er at det kan vanskeliggjøre den tematiske avgrensingen i undersøkelsen, mens en styrke er at informantene får mulighet til å bringe på banen relevante fortellinger og temaer, som kan bidra til å få fram nyansert kunnskap om det forskningsspørsmålene etterspør (jf. Krumsvik, 2019, s. 166). I etterkant av intervjuene ser jeg at det kunne ha vært en fordel å be informantene selv definere begrepene loeremidler og kultur-og demokratiforståelse, da det kunne ha virket oppklarende. På den annen side ønsket jeg ikke at forhåndsdefinisjoner skulle være styrende for samtalen, siden intensjonen var "å ta pulsen" på hva som skjer i praksisfeltet. Hva informantene la i disse begrepene, kom derfor indirekte fram gjennom eksemplene de ga.

\section{Design og gjennomføring av pilotundersøkelsen}

I forkant av pilotundersøkelsen designet jeg en enkel intervjuguide bestående av tre innledende spørsmål og en hoveddel. Den innledende delen var mer lukket og strukturert enn hoveddelen, da målet var å innhente konkret informasjon, som kunne danne et utgangspunkt for resten av intervjuet. 
— Hvor lenge har du jobbet som spansklærer?

- Bruker du et bestemt læreverk i din spanskundervisning? Hvor lenge har du brukt det?

— Hvem har valgt ut læreverket, og vurderer du/dere å bytte det ut? I så fall, hvorfor?

Jeg la opp til at hoveddelen av intervjuet skulle være relativt utstruktuert og uformelt, og stilte to innledende spørsmål:

— Hvordan tilrettelegger du spanskundervisningen for å styrke elevenes kulturinnsikt og demokratiforståelse?

— Kan du gi noen eksempler på læremidler du bruker og aktiviteter du legger opp til for å nå disse målene, og begrunne hvorfor?

Tre spansklærere på ungdomstrinnet deltok i pilotintervjuene. De ble gjennomført i fysiske intervjuer ved deres respektive skoler, og varte i cirka 45 minutter. Jeg lot lærerene selv bestemme hvilke eksempler de ville trekke fram, og jeg stilte oppfølgingsspørsmål der jeg fant det relevant. Dette ga meg stor fleksibilitet og mulighet til å gå inn i intervjuet med en åpen og undersøkende holdning (jf. Merriam \& Tisdell 2016, s. 110-111).

\section{Transkripsjon, bearbeiding og fortolkning av innhentet materiale}

Under intervjuene tok jeg notater, ikke lydopptak. I kvalitative forskningsintervjuer som jeg har gjennomført tidligere, har jeg hatt inntrykk av at noen informanter legger bånd på seg selv og er mindre åpne når det gjøres lydopptak, mens for andre har det ingen betydning for hvor åpne og spontane de er. Lyd-/filmopptak kan være til hinder for forskerens forsøk på å skape en hyggelig og fortrolig atmosfære i intervjuesituasjonen, men det kan også virke forstyrrende at forskeren sitter og tar notater under intervjuet (Merriam \& Tisdell, 2016, s. 128; 131). Selv om man gjør lydopptak, kan man gi rom for å supplere med eventuell relevant informasjon som fremkommer etter at mikrofonen er slått av (under betingelse av at informantene gir sitt samtykke) (Kvale \& Brinkmann, 2009, s. 142). Jeg bestemte meg likevel for å utelate lydopptak, da jeg tenkte at det ville være lettere for intervjupersonene å snakke fritt og åpent. 
Jeg renskrev notatene umiddelbart etter intervjuene, og la hvert intervju inn i et Word-dokument. Det vil si, det ble ikke gjennomført en fullstendig transkripsjon av innholdet i intervjuene, men jeg forsøkte å beholde den røde tråden og hovedessensen i informantens beretninger (jf. Kvale \& Brinkmann, 2009, s. 212). I etterkant av intervjuene ser jeg at det likevel ville vært en fordel å gjøre lydopptak, da dette hadde spart meg for en god del tid i etterkant på å forsikre meg om at jeg hadde fått med meg den viktigste informasjonen, og at denne var korrekt. I de tilfellene der jeg var i tvil om jeg hadde notert feil, manglet eller hadde misoppfattet noe, kontaktet jeg den aktuelle intervjuepersonen på e-post/Skype, og ba om oppklaringer. Disse oppklaringene førte blant annet til at jeg fikk mer utfyllende informasjon om audiovisuelle kilder som lærerne benyttet og mer detaljerte eksempler på språklige og kulturelle temaer de fokuserte på i tilknytning til disse. Med lydopptak ville jeg også hatt større mulighet til å oppdage eventuelle detaljer som jeg ikke tilla stor betydning under intervjuene, men som muligens kunne ha bidratt til å utdype og nyansere resultatene.

I bearbeidelsen og fortolkningen av det innhentede materialet anvendte jeg en narrativ tilnærming i den forstand at jeg organiserte hver delfortelling i tematiske hovedkategorier, og forsøkte å beholde helheten og den indre logikken (den kronologiske rekkefølgen), såkalt holistic approach (jf. Merriam \& Tisdell 2016, s. 231-232). For å ivareta validiteten av hovedundersøkelsen sendte jeg mitt førsteutkast til artikkelteksten på e-post til informantene, slik at de kunne korrigere eventuelle mangler og mistolkninger.

I presentasjonen av resultatene har jeg valgt ut enkelte delfortellinger som tematisk sett gjenspeiler noen av hovedtendensene jeg kunne utlede fra det innhentede materialet. Funnene må sees i lys av at disse viser et lite utsnitt, og ikke en helhetlig oversikt, av hvordan de intervjuede lærerene velger ut og bruker læremidler i sin undervisning. Undersøkelsens begrensede omfang gir ikke tilstrekkelig grunnlag til å trekke noen generelle konklusjoner.

\section{Resultater og diskusjon}

\section{De deltakende lærernes undervisningserfaring i spansk}

Pilotundersøkelsen 2018: Av de tre ungdomsskolelærerne som deltok, hadde én mer enn 10 års undervisningserfaring, mens de to resterende hadde mellom tre til ti års erfaring. Lærene jobbet på tre ulike skoler fordelt på tre ulike kommuner sørøst i Norge. 
Intervjuundersøkeslen 2020/21: Av de 14, ungdomsskolelærerne som deltok, hadde fire mer enn 10 års undervisningserfaring og sju hadde mellom 5 og 10 års erfaring. Av de tre resterende hadde én jobbet 3,5 år i ungdomsskolen, mens de to siste hadde jobbet 1,5 år. Informantene jobbet på 12 ulike skoler, fordelt på 12 ulike kommuner sørøst i Norge. Det vil si at alle jobbet på forskjellige skoler, med unntak av to som jobbet ved samme skole i Oslo, og to som jobbet ved samme skole i en av Oslos nabokommuner. Det er følgelig relativt god spredning med hensyn til lærerenes undervisningserfaring og kommunetilhørighet, men studien mangler nyutdannede nytilsatte lærere.

Resultatene viser følgelig ikke hvilke erfaringer lærere med mindre enn ett års erfaring har gjort seg med valg og bruk av læremidler i spansk. Dette er imidlertid et forskningstema som bør utforskes nærmere, for eksempel hvordan ferske spansklærere opplever sitt første arbeidsår, herunder hvilke utfordringer de møter når de jobber med kulturelle temaer i spanskundervisningen, hvorvidt de selv opplever å bli inkludert i det profesjonelle fellesskapet, og hvordan.

\section{Valg av læreverk i spansk på makronivå}

Når det gjelder valg av læremidler på makronivå, det vil si, læremidler som læreren planlegger å bruke i tilknytning til bestemte aktiviteter i en halv- eller årsplan (Hansen, 2010), rapporterte alle informantene, med unntak av to, at de bruker et papirbasert læreverk i spansk. $\mathrm{Ni}$ av informantene bruker papirbaserte læreverkserier (med tilhørende fagnettsted) fra perioden 2004-2008, henholdsvis Amigos (Riquelme, Salomonsen, Knutagård, de la Motte \& Lizanam, 2004; 2005; 2006); ;Vale! (Hanson \& Teva, 2006; 2007; Hanson, Teva \& Klingenberg, 2008) og Chicos Chicas (Cleaverley, Dybwad, Ferragut \& Palomino, 2005a; 2005b; 2006). Alle disse utkom i forbindelse med innføringen av Kunnskapsløftet (LKo6), og er beregnet for spansk nivå I på ungdomstrinnet. Seks informanter bruker den papirbaserte læreverkserien Gente (med tilhørende nettressurser) (Børve, Fjerdingren, Hernández, Manjón \& Sveia-Nilsen, 2018; 2019a; 2019b), mens to bruker den digitale utgaven av samme serie.

På det norske læremiddelmarkedet er Gente per i dag den eneste læreverkserien av nyere dato som er beregnet for spansk nivå I på ungdomstrinnet (LKo6/LK20). Vel halvparten av informantene bruker altså læreverk som er cirka 15 år gamle. Alle disse oppgir imidlertid at de også benytter de gratis nettressursene til Gente.

Alle informantene oppgir at valg av læreverk i spansk skjer gjennom faglige og pedagogiske vurderinger innad i lærerkollegiet. Dette funnet er i tråd med funn fra tidligere studier i norsk skole, som viser at det stort sett er lærerkollegiet, ikke administrasjonen, som 
foretar valg og kvalitetssikring av læreverk (Skjelbred, 2019, s. 67). Åtte av informantene uttrykker sterkt ønske om å bytte til et nyere læreverk, men har foreløpig ikke hatt anledning til det. De opplever ikke at det skyldes uvilje fra skoleledelsens side, men stram skole- og kommuneøkonomi. De har forståelse for at skoleledelsen må foreta prioriteringer ved innkjøp av bøker, og at behovet kan være mer prekært i andre fag enn spansk. Et par av informantene foretrekker å vente noen år før skolen kjøper inn nytt læreverk i håp om at flere norske forlag skal komme med nyutgivelser i spansk. Det er $\emptyset$ nskelig med et større utvalg enn bare læreverkserien Gente. Ett hovedkriterium i valg av nytt læreverk er at det er utarbeidet med tanke på norsk skolekontekst og fagfornyelsen (LK2O). Når det gjelder hvilke andre kriterier lærerne legger til grunn for valg av lærebøker i spansk på ungdomsskolen, for eksempel i hvor stor grad lærebokas kultursyn har en betydning, er et felt som bør undersøkes nærmere, gjerne i et komparativt perspektiv med andre skandinaviske eller nordiske land.

De åtte informantene som bruker lærebokserien Gente mener at den generelt sett er mer opplevelsesorientert og viser et bredere spekter av den spanskspråklige verden enn tidligere lærebokserier. Hvilken betydning dette har for elevenes syn på den spanskspråklige verden sammenlignet med elever som bruker lærebokseriene publisert på tidlig 2000-tallet, er vanskelig å si basert på det innhentede datamaterialet i denne undersøkelsen. Mer presise og utfyllende svar på dette vil kreve mer systematiske, komparative lærebokanalyser og undersøkelser, der også elevperspektivet trekkes inn.

\section{Utdaterte læreverks potensielt didaktiske potensiale og elevsentrering}

De ni informantene som bruker læreverk som er cirka 15 år gamle (Amigos, ;Vale! og Chicos Chicas) oppgir at dette tidvis skaper frustrasjon. I tekstbøkene er for eksempel faktatekster/-bokser med nøkkelinformasjon om utvalgte spansktalende land (opplysninger om befolkningstall, navn på politiske ledere og lignende) utdaterte. Det samme gjelder tekster og bilder av artister, skuespillere, idrettstjerner med flere, som var populære i 1990-årene og på tidlig 2000-tallet, for eksempel skuespilleren Antonio Banderas og musikkartister som Juanes og Gloria Estefan. Ifølge informantene har dagens ungdom liten eller ingen kjennskap til disse, og de klarer ikke å koble dem til egen livsverden. Dette funnet samsvarer med funn hos Eide (2012; 2013) som viser at en av risikoene med å inkludere populærkulturelle temaer i lærebøker, er et de raskt kan miste sin aktualitet og relevans. 
Informantene som jobber med disse læreverkene ser dermed nødvendigheten av å aktualisere lærestoffet i undervisningen. Seks av dem beskriver hvordan de forsøker å utnytte det didaktiske potensialet som de utdaterte lesetekstene i læreboka gir, ved å legge opp til læringsaktiviteter som passer til elevenes læreforutsetninger og som har relevans i deres liv (jf. Munthe, 2020, s. 223). I fire av disse eksemplene får elevene i oppdrag å oppdatere de utdaterte læreboktekstene. De må finne fram til troverdige kilder, som kan gi dem oppdatert, korrekt og utfyllende informasjon. Elevene står fritt til å utføre sine informasjonssøk på ulike språk, som spansk, norsk, engelsk og eventuelt andre språk de behersker, men de må framstille resultatene av søkene på spansk. Slik kan de oppleve å støte på motstridene informasjon, eller ulike vinklinger og perspektiver, samtidig som de får utnyttet sin flerspråklighet i informasjonss økene og -bearbeidingen. I to andre eksempler finner elevene fram til spansktalende artister, idrettsstjerner og andre kjente personligheter, som appellerer til dem, og begrunner hvorfor. Alle må presentere sine funn for sine medelever. Presentasjonsformen velger elevene selv etter fastsatte kriterier som lærer og/eller elever har laget på forhånd. Disse kan være forståelsesmedier som muntlige eller mulitimodale presentasjoner, lydfiler, filmopptak og lignende. Slik skapes elevproduserte læremidler (jf. Llovet Vilà, 2019, s. 306), som fungerer som parallelle og alternative tekster til lesetekstene i de utdaterte lærebokene.

Gjennom oppgavene beskrevet ovenfor får elevene anledning til utvikle både fagspesifikke og fagovergripende kompetanser, som kreativitet, fordypning og kildekritisk tenkning. De eksponeres ikke bare for informasjon fra læreboka, men må sammenstille informasjonen de trekker ut fra den med informasjonen de har innhentet gjennom egne kildesøk. De får dermed trening i å bruke en mengde informasjon, og å forholde seg kritisk til denne (jf. Gamlem \& Rogne, 2016, s. 64; 104). Samtidig får elevene brukt sine kreative evner og språkferdigheter: I videreformidlingen av den nyervervede kunnskapen til sine medelever skaper elevene ulike produkter. Slik får de vist fram ulike sider av seg selv, da forkunnskapene deres er forskjellige, de engasjerer seg ulikt, vurderer den innhentede informasjonen ulikt og mestrer ferdighetene ulikt (Gamlem \& Rogne, 2016, s. 32-33). 


\section{Autentisk språkbruk og bruk av dialoger som modelltekster}

I tilknytning til den kulturelle dimensjonen i språkfag er de ulike formene for språkbruk som elevene eksponeres for av interesse fordi de inngår i bestemte kulturelle og sosiale praksiser, og fordi de utgjør en integrert del av en større sosial og kulturell sammenheng (jf. Risager, 2018).

En utfordring ved lærebøkene produsert i perioden 20042008 var, ifølge fire av informantene, dialogtekstene. Fra deres synspunkt gjenspeiler tekstene hvordan hverdagslige samtaler føres i det virkelige liv. Tekstene egner seg dermed lite som modelltekster når elevene selv skal skape dialoger og øve på å tilpasse budskapet mottaker og kommunikasjonssituasjon (pragmatisk kompetanse). En av informantene poengterer følgende:

99 Dialogene i lærebøkene fra tidlig 200o-tallet framstår som oppkonstruerte og unaturlige. For eksempel inneholder bøkene dialoger som skal illustrere uformelle samtaler i dagligdagse situasjoner, men midt i dialogene kommer plutselig generelle faktaopplysninger, som ikke hører naturlig hjemme i uformelle samtaler. Det er vel ingen som snakker sånn!

(Anne, spansklærer, 9. og 10. trinn)

De fire informantene oppgir at de heller bruker andre tilpassede og autentiske dialogtekster, hvor samtalepartnerens formuleringer og innholdet faller mer naturlig inn i samtalene. Disse henter de fra andre didaktiske semantiske læremidler produsert i Norge, eller andre land, som Spania, USA, Sverige og Danmark, på YouTube, fra filmer og lignende.

Også de andre informantene nevner ett eller flere eksempler på ulike autentiske lyd- og audiovisuelle kilder som de benytter for å eksponere elevene for naturlig tale. En av dem gir som eksempel tv-konsepter som Nail it, Masterchef og La Voz (The Voice). Disse er gjenkjennelige for elevene fra fritiden. Fordelen, ifølge informanten, er at de finnes i ulike versjoner i ulike spansktalende land, som Nail it (México) og Nail it (España). I arbeid med denne type programmer får elevene i oppgave å feste seg ved dialogene som oppstår når deltakerene for eksempel skal løse de ulike matlagings-, bake- og konditoroppgavene, som ord og standardfraser de kjenner igjen, ord de vil vite betydningen av, beskrive utvalgte kaker, personer i programmet, hva de gjør, hvordan de reagerer og hvorfor, osv. Dette gir grunnlag for å diskutere med elevene hvilke kulturelt betingede elementer som manifesterer seg i dialogene. 
I løpet av intervjuene kommer et par av informantene inn på at de synes det er utfordrende å lære elevene forskjellene på formell og uformell stil på spansk, for eksempel i hvilke samtalesituasjoner og kontekster man bruker høflighetsformer, og hvilke ikke. På norsk brukes knapt høflighetsformen De lenger, og elevene har derfor få referansepunkter. På spansk, derimot er bruken utstrakt, og det er store variasjoner i bruken av De-formen (usted; ustedes), både i et dialektalt og sosiolingvistisk perspektiv. Dette er et komplekst tema, som man jobber mer inngående med på høyere utdannelsesnivåer, og informantene spør seg derfor selv hvordan de kan forklare dette fenomenet uten å komplisere det unødig. Følgende uttalelse er representativ:

99 Det viktigste for meg er at elevene klarer å føre enkle dialoger, stille spørsmål og svare på sitt språknivå, og at de tør å bruke og utforske språket. Det er bedre at de klarer å produsere setninger på spansk enn at de stopper opp, fordi de er usikre på om de skal bruke tú [du] eller usted [De]. For meg holder det at de får med seg at det eksisterer noen dialektale, sosiale og kulturelle forskjeller når det gjelder valg av ord og bruk av standard- og høflighetsfraser. De trenger ikke å huske og beherske alle, eller sette seg grundig inn i de ulike variantene som brukes.

(Hanna, spansklærer, 8.-10. trinn)

Hvordan ulike typer autentiske lyd- og audiovisuelle kilder utnyttes for å styrke den pragmatiske og interkulturelle kompetansen til elever tidlig i tenårene, og for å presentere dem for ulike stemmer og perspektiver, er temaer det kan forskes mer inngående på.

\section{Læreboka og lærerens egne erfaringer som styrende for temavalg?}

Alle informantene oppgir at læreboka ofte danner utgangspunkt når de velger temaer for spanskundervisningen, men ikke nødvendigvis alltid. I arbeidet med kulturorientert innhold benytter de vanligvis lesetekster, ordinnlærings- og grammatikkoppgaver i læreboka som føraktivteter, slik at elevene kjenner til betydningen av bestemte ord og behersker relevante grammatiske strukturer før de introdusere dem for andre kilder om de valgte temaene. 
Med hensyn til det kulturorienterte innholdet, kommer halvparten av informantene inn på dilemmaer når det gjelder valg av temaer og land, begrenset med tid og hvor bredt/dypt de skal gå inn på hvert enkelt tema/land/område. Den spanskspråklige verden representerer et stort språklig, kulturelt, sosialt, politisk og økonomisk mangfold, og det er umulig å dekke alle kulturelle aspekter. Når det gjelder valg av temaer i tilknytning til dagligliv, baserer informantene seg i stor grad på temakapitler i læreboka med tilhørende ressurser på fagnettsted, det være seg temaer som skole- og familieliv, ferie og fritid, matkultur, musikk og sang, ungdomskultur, vaner og rutiner, høytider og feiringer (kultur med liten k). Informantene finner det ikke vanskelig å gjøre disse temaene relevante og knytte dem til elevenes liv, for eksempel ved at elevene forteller om egen skolegang, venner, fritid og familieliv og sammenligner disse aspektene med med det som beskrives i læreboka. Så lenge temaene er knyttet til den personlige sfæren, skaper det heller ikke store språklige utfordringer, da elevene kan jobbe på sitt nivå. Går temaene utover den personlige sfæren, kreves det imidlertid mer tilrettelegging fra deres side, både språklig sett og med tanke på å finne knagger som elevene kan henge kunnskapene sine på.

Når det kommer til spansktalende land som presenteres i lærebøkene som brukes, gis det i starten ofte en kortfattet presentasjon av alle spansktalende land med tilhørende bilder (landskap, severdigheter, kjente personligheter o.l.). Deretter fokuseres det på utvalgte land i enkelte kapitler. Land som er fremtredende i lærebøkene og som nevnes hyppig av informantene er Spania, Argentina, Cuba, Chile og Mexico, men det er også lærebøker, som Chicos Chicas og Gente, som inkluderer et større spekter av land. Landpresentasjonene gis som regel på en nøytral måte i form av faktatekster, der særlig geografisk beliggenhet, klima, landskapsformasjoner, innbyggertall, etnisk befolkningssammensetning, severdigheter, råvarer/eksportvarer, fauna og lignende, fremheves (jf. lignende funn i Risager 2018; Risager \& Svarstad, 2020, s. 89). Dette skaper relativ stor distanse mellom teksten og elevene, dels på grunn av den upersonlige stilen, dels på grunn av elevenes manglende forkunnskaper om det aktuelle landet. For å skape nærhet til og levendegjøre lærestoffet, sier vel halvparten av informantene at de ofte velger land og temaer som de har god kjennskap til fra før og som de kjenner seg trygge på: De deler med elevene personlige erfaringer fra steder og land som de selv har bodd eller oppholdt seg i, jf. tilsvarende funn i studier på gymnasnivå i Danmark (Fernández, 2019, s. 87). I den forbindelse vektla en informant fordelene av å sitte med førstehåndskunnskap: 
Jeg følger ekstra med på samfunnsutviklingen i land der jeg har bodd. Da blir det lett til at jeg også setter ekstra fokus på disse landene i undervisningen. Ikke fordi jeg mener at disse er mer interessante og viktigere enn andre spansktalende land og steder, men fordi det blir lettere å presentere dem for elevene på en nyansert måte: Jeg kan gå dypere inn på kulturelle og samfunnsmessige aspekter og vise flere sider ved samme sak, nettopp fordi jeg sitter med førstehåndskunnskap og egne erfaringer. Jeg følger jo med på dagsaktuelle saker i andre spansktalende land også, men føler noen ganger at forklaringene mine blir litt overfladiske når jeg skal utdype disse.

(Christina, spansklærer 9. og 10. trinn)

Lærebøkenes faktatekster om spanskspråklige land kjennetegnes ved at historiske og politiske begivenheter (kultur med stor K) presenteres sporadisk og kortfattet, uten at disse kontekstualiseres i nevneverdig grad, jf. risikoen for overforenklinger/reduserende framstillinger av land og nasjoner i lærebøker, samt at nasjoner framstilles som noe fast og stabilt (Risager \& Svarstad, 2020, s. 86; 89). En av informantene trekker fram som eksempel at det i læreboktekstene kan stå "durante la dictadura", eller "después de la dictadura" uten at det forklares hvilket diktatur det er snakk om, fra hvilken periode, hva diktatoren het, hvorfor diktatur/demokratiske styreformer oppstod og lignende. Informantene, og da særlig de som bruker læreverk fra tidlig 2000tall (se ovenfor), opplever derfor at de må bruke tid på å forklare konteksten og supplere med mer illustrerende og informative kilder.

En risiko ved at lærerne baserer seg mye på læreboka, er at den blir styrende for temautvalgene i spansktimene, at læreboka definerer hvilke kulturspesifikke temaer som tas opp, på bekostning av eventuelt andre, likeså relevante temaer. I St. Meld. nr. 28 (2015-2016) understrekes det at innholdsorienteringen ikke skal være for detaljert slik at den begrenser lærernes mulighet for å velge aktuelt innhold og tilpasse opplæringen til elevene (St. Meld. nr. 28 (2016), s. 44). I den forbindelse kan man stille spørsmål om de senere års lærebøker, i rollen som læremiddellærer, har overtatt noen av de samme funksjonene som tidligere, mer innholdsorienterte læreplanverk hadde. Skjelbred (2019, s. 74) poengterer at etter hvert som elevaktiv undervisning og læring gjorde seg stadig mer gjeldende som prinsipp i norsk skole i løpet av 190o-tallet, så har lærebokforfattere (læremiddellæreren) på mange måter overtatt klasseromlærerens funksjon: De inntar en mer aktiv rolle, og kommer med direkte seg 
oppfordringer til elevene om hvordan de skal handle og forholde seg til lærestoffet, det være seg gjennom instruksjoner av typen "gå sammen i grupper", "still tre spørsmål", eller ved å tale direkte til elevene i lærebokas forord (Skjelbred, 2019, s. 74-75).

Funn i denne undersøkelsen kan tyde på en lignende tendens i lærebøkene i spansk: En informant ga som eksempel på "læremiddellæreren" et kapittel hentet fra læreverkserien Gente med tittelen Viajes [Reiser]: Elevene oppfordres til å lese tre tilpassede tekster, feriehilsener, i form av ett postkort fra Costa Rica, en sms fra Mallorca og en e-post fra Uruguay. Deretter blir de bedt om å bruke disse som modelltekster for å skrive egne imaginære hilsener i de samme teksttypene. De velger selv fra hvilket land og sted, men må forholde seg til tre innholdskriterier: hvor de er, hvor de har vært og planer for resten av ferien. Læremiddellæreren blir følgelig styrende også for sjangervalg og innholdskomponent når elevene selv skal produsere tekster i tilknytning til temaet. Denne type eksempler er i tråd med funn hos Eide (2013, s. 7-8) om at fremstillingen av spansktalende land ofte er forbundet med ferie og reiser.

For å utvide elevenes horisont og inkludere flere land, byer og regioner enn de som omtales i læreboka, er en vanlig framgangsmåte, ifølge informantene, å sette i gang prosjekter der elevene selv velger hvilket land eller område de skal jobbe med og fordype seg i. Deretter legger man opp til fellesaktiviteter, der elevene presenterer det valgte landet/området, foretar sammenlikninger, diskuterer likheter og forskjeller osv. Informantene fremhever at det selvsagt er varierende blant elevene hvilke forkunnskaper de har om de enkelte spansktalende landene og spanskspråklige kulturer. Vanligvis, når de starter med et tema, aktiverer de elevenes forkunnskaper på ulike måter. Et gjennomgående eksempel er idémyldring (brainstorming), i par, mindre grupper og/eller plenum, gjennom bruk av bilder, videosnutter, tankekart o.l. To av informantene kommer inn på at $\mathrm{i}$ aktiveringen av elevenes forkunnskaper blander elevene ofte typiske kulturelle kjennetegn fra Spania og de ulike latinamerikanske landene. Eksempelvis kan elevene forbinde tradisjonelle mexicanske matretter med Spania, tradisjonelle musikkstiler fra Spania med Mexico osv. Dette handler om hvordan elevene organiserer kunnskapen sin, og er et tema som kan undersøkes nærmere. Elevene skiller kanskje ikke tydelig mellom de ulike nasjonalstatene, eller tenker i binære par (nord/sør, Spania/Latin-Amerika, der hele Latin-Amerika sees under ett), slik lærebøkene tradisjonelt har hatt en tendens til å gjøre (jf. Risager, 2018), men i binære par som spansktalende/ikkespansktalende, eller de betrakter verden på en annen måte enn man har gjort tidligere. 


\section{Digitale semantiske læremidler og bruk av strømmetjenester}

I løpet av intervjuene kom alle informantene i større eller mindre grad inn på den enorme betydningen digitaliseringen har hatt, med tanke på tilgang til ulike kommunikasjonsmedier. Når det gjelder kontaktmedier, har for eksempel strømmetjenestene gjort tilgangen til spanskspråklig musikk og sang, filmer og serier mye enklere. Dermed blir det også lettere, ifølge informantene, å bygge broer mellom formell og uformell læring (jf. eksempelet ovenfor med Nail it). Nedenfor følger et par illustrerende eksempler på hvordan elevenes kulturelle bevissthet og faglige engasjement kan styrkes:

\section{Spanskspråklige serier, sjangerkompetanse og kulturell bevissthet:}

Én informant beskrev hvordan hun legger opp til bevisstgjørende samtaler på norsk, der hun blant annet diskuterer innholdet i og sjangertrekkene til de spanskproduserte ungdoms- og spenningsseriene Élite [Eliteskolen] og Casa de papel [Papirhuset]. De fleste av elevene har sett disse seriene på fritiden. Målet hennes med disse samtalene er å få elevene til å reflektere over hvilke virkemidler som brukes, at det dreier seg om fiksjonsserier, og at det som vises i disse seriene ikke alltid stemmer overens med virkeligheten. Eksempelvis ber hun elevene sammenligne Élite med nordamerikanske high school-serier, som elevene også kjenner til. Da oppdager de at serien på mange måter minne mer om en amerikansk high school-serie enn en spansk skolehverdag.

\section{Spanskspråklige sanger og elevmedvirkning:}

En annen inviterer elevene til å oppdage spanskspråklige sangers potensielt didaktiske potensiale ved at hun har opprettet en felles spilleliste, "klassens spansksanger". Den inneholder forslag til sanger som kan brukes i undervisningen, og nye sanger kan legges til gjennom hele skoleåret. Elevene og læreren bestemmer sammen hvilke av sangene de skal jobbe med i spansktimene, og på hvilke måter. Noen ganger er det for å trene lytteforståelsen (gjenkjenne ord, finne ut hva sangen handler om), andre ganger for å utforske den kulturelle konteksten sangen oppstod i. Elevene er oppdaterte på hva slags musikk dagens ungdom lytter til, og kan besitte kunnskaper om musikkartister- og sjangere som gir dem mening (jf. Tomlinson, 2012, s. 346; Risager \& Svarstad, 2020, s. 141). Samtidig introduserer læreren, gjennom sine forslag, elevene for andre artister, for eksempel fra andre tidsepoker og sjangere.

Å lytte til musikk har en estetisk og følelsesmessig dimensjon, jf. appreciative music (Wolvin \& Coakley, 1996, s. 366), og det å gjøre det 
til et felles klasseprosjekt bidrar til å styrke de sosiale og faglige båndene lærer-elev og elevene imellom, jf. faktorer som elev- og felleskapssentrering (Munthe, 2020, s. 221; 230).

\section{Bruk av sang og musikk for å styrke elevenes demokratiforståelse}

Alle informantene oppir at de bruker spanskspråklig sang og musikk på en eller annen måte. To av dem ga utførlige eksempler på hvordan de bruker sanger for å styrke elevenes leseforståelse og begrepsapparat: Elevene får utdelt sangtekster på spansk. Noen av dem har vært forbudte i perioder, andre ikke. Elevene skal så gjette seg fram til hvilke som har vært forbudte, og hvorfor. Deretter jobber elevene parvis og setter seg mer inngående inn i tekstinnholdet $\mathrm{i}$ utvalgte sanger. Det kan for eksempel være to versjoner av én og samme sang, én sensurert og én usensurert versjon. Elevene skal forsøke å identifisere forskjellene i de to versjonene, undersøke hva de består av, og hvorfor. Den pedagogiske tanken bak bruken av disse sangene er at elevene, for å kunne løse oppgavene, må sette seg inn i sangenes budskap, deres historiske og politiske kontekst. Slik stifter elevene kjennskap til sanger som bærer på viktige historier, og i forbindelse med disse jobber de med begreper som sensur, ytringsfrihet, politisk undertrykkelse, diktatur og demokratiske rettigheter.

Disse læringsaktivitetene kombinerer musikalske uttrykk med forståelsesmedier som gjettelek og sammenligninger. Med tanke på aktivitetens aktualiserte didaktiske potensiale, har de to lærerne erfart at de er faglig utfordrende for elevene, da det fordres at de klarer å relatere sanginnholdet til historiske begivenheter og perioder, samt ulike politiske styreformer og ideologier. Selv om elevene har lært en god del om dette i samfunnsfag/historie, er det nødvendigvis ikke slik at de klarer å iverksette denne kompetansen i arbeidet med sangene. Det trengs derfor mye tid til føraktiviteter, slik at elevene kan knytte de nye begrepene og konseptene til tidligere kunnskaper og erfaringer (jf. Sawyer, 2014, S. 5). Erfaringsmessig synes elevene likevel at aktiviteten er både morsom og lærerik.

\section{Bruk av personlige uttrykksformer for elevenes demokratiforståelse}

Som et ledd i å styrke elevenes interkulturelle kompetanse kan man involvere eksterne aktører i spanskundervisningen (jf. Fernández, 2019, s. 88). Informantene ga få eksempler på samarbeid med eksterne aktører, men en av dem beskrev detaljert hvordan hun hvert skoleår inviterer en person av chilensk opprinnelse i nærmiljøet i tilknytning 
til et undervisningsopplegg på 9. trinn (elever i 14-års alderen) om Chiles nyere historie og aktuelle situasjon. Denne personen, "Antonio", var tenåring da han opplevde militærkuppet i 1973. Deretter dro han alene i eksil og fikk asyl i Norge. Før besøket gjør elevene en rekke føraktiviteter. De får i hjemmelekse å finne aktuelle nyhetsartikler om Chile i norsk presse og presentere disse på norsk i den påfølgende spansktimen. Gjennom hjemmeleksen erfarer elevene at det er begrenset hvor mange artikler/reportasjer de klarer å finne fram til. Læreren tilrettelegger derfor for en reflekterende diskusjon, der hun spør elevene hva de tror dette skyldes, og hvorfor. Deretter gir hun dem tips til andre engelsk- og spanskspråklige kilder, som elevene kan oppsøke. Ifølge informanten, er én utfordring med spanskspråklige nyhetskilder komplisert språk, langt over elevenes språknivå. Dette gjør at elevene får mulighet til å trene på ulike lese- og kompensasjonsstrategier for å sikre tekstforståelsen, som å støtte seg på bilder og digitale tv-innslag, se på/lytte til overskrifter, gjenkjenne enkeltord, fraser og lignende (jf. Gamlem \& Rogne, s. 69-70).

Under selve besøket deler "Antonio" personlige fortellinger på norsk med elevene om hvordan han opplevde militærkuppet og den senere gjeninnføringen av demokratiet. Underveis kan elevene stille spørsmål om ting de lurer på. Læreren har inntrykk av at denne type personlige historier gjør dypt inntrykk på elevene. I tillegg gjør den narrative tilnærmingen i form av små, personlige førstehåndsberetninger, eller øyevitneskildring, at elevene klarer å skape seg en bedre forståelse av begreper som militærkupp, sensur, unntakstilstand, portforbud, korrupsjon, o.l.:

99 Når elevene leser informative tekster i læreboka, der slike begreper benyttes, får de ikke så mye ut av teksten, men når de får høre historier fra en virkelig person som har opplevd dette, klarer de å forestille seg hva begrepene betyr på en helt annen måte. (Annette, spansklærer, 9. trinn)

For å tilrettelegge for forsterkning av elevenes læring, viser læreren, i første spansktime etter Antonios besøk, fiksjonsfilmen Machuca (Wood, 2004), som omhandler to 11 år gamle gutters opplevelser av militærkuppet. Til slutt gjennomfører hun fagsamtaler med hver enkelt elev, der de får anledning til å reflektere over hva de har lært og uttrykke personlige inntrykk av den felles opplevelsen (jf. Gamlem \& Rogne, s. 32-33). 
Danningsfremmende undervisning kan bidra til å gjøre elevene mer bevisste nøkkelspørsmål i sin samtid (jf. Ulvik \& Sæverot, 2020, s. 3738). Undervisningssyklusen beskrevet ovenfor kan bidra til å ta opp et tidsaktuelt tema med elevene, som at vi ikke kan ta demokratiet og demokratiske verdier for gitt. En annen informant har brukt en annen type personlig uttrykksform, en tweet publisert av fotballspilleren Gary Medel, for å sette søkelyset på massedemonstrasjonene mot myndighetene i Chile i 2019. Tweeten bestod av enkle, punktvise forklaringer på årsakene til folkeprotestene. Tweeten dannet grunnlag for sammenligninger mellom levevilkår i Norge og Chile og ytterligere informasjonssøk om Chile og alt det nye som elevene hadde oppdaget.

Fire av informantene fremhevet bruk av kart- og bildetjenester, som Google Maps og Googles Street View, for å sette igang bevisstgjørende læreprosesser hos elevene om sosiale og $\emptyset$ konomiske forskjeller. I ett av eksemplene skulle elevene kartlegge by- og landskapsarkitekturen i Norge og ulike spansktalende land. Gjennom sine søk oppdaget de blant annet at skolebygningenes plassering, utseende og forfatning varierte veldig på tvers av land, men også innad i hvert land, i hver region og i hver by. Eksempelvis observerte elevene at enkelte steder var skolebygningene gamle, slitte og forfalne, mens i andre var de nye og moderne. Mens noen skoler lå i velstandsstrøk, lå andre i fattige bydeler. Det innhentede visuelle materialet dannet så utgangspunkt for samtaler dem imellom om $ø$ konomiske skjevheter og ulike utdanningsmuligheter.

I eksemplene overfor fungerer nyhetsartikler og -reportasjer, personlige og filmatiske uttrykksformer, digitale karttjenester, som medier som fasiliterer kontakt med lærestoffet, og som åpner opp for ulike innfallsvinkler og perspektivtakinger (jf. Hansen, 2012a, s. 23). Gjennom de ulike forståelsesmediene som det legges opp til (lese, lytte, observere, presentere, stille spørsmål, sammenligne, diskutere), får elevene bearbeidet lærestoffet, slik at de selv kan skape seg en formening om hva som skjer når demokratiske institusjoner og prinsipper settes til side, og hvordan dette påvirker enkeltindividets hverdagsliv og livsløp, både når det gjelder rolle og status (jf. Stray, 2011, s. 14). Elevene får også trening i empatisk lytting, som blant annet innbefatter å oppfatte andres tanke- og følelsesliv, både kognitivt og affektivt (jf. Adelmann, s. 2009, s. 165), noe som er essensielt i utviklingen av interkulturell kompetanse.

\section{Fler- og tverrfaglige tilnærminger}

Sju av informantene ga eksempler på fler- og tverrfaglige tilnærminger som, i tillegg til språk, involverer praktisk-estetiske fag som Mat og helse og/eller Kunst og håndverk. Fire av eksemplene var flerfaglige, 
og gikk hovedsakelig ut på at spansklæreren alene stod for et opplegg der elevene brukte skolekjøkkenet til å lage matretter fra spanskspråklige områder, eller inkluderte kunstfaglige elementer i egen undervisning. Av tverrfaglige prosjekter utpekte ett prosjekt seg: Fagene fransk, spansk, tysk, arbeidslivsfag og mat og helse kobles sammen, Som hovedaktivitet skal elevene lage en tradisjonell matrett fra fire språkområder. Hovedmålene med prosjektet er å skape faglig entusiasme, styrke elevenes praktisk-estetiske ferdigheter, språkkompetanse og evne til kulturformidling og øke deres relasjonskompetanse og felleskapsfølelse. Disse operasjonaliseres ved at elevene skal gjøre en rekke føraktiviteter, som fungerer som forberedelse til hovedaktiviteten. Føraktivitetene består blant annet av følgende:

— lese og forstå en autentisk matoppskrift på henholdsvis fransk/ spansk/tysk/engelsk;

- se eksempler på hvordan den valgte matretten tilberedes på YouTube eller lignende;

— lære seg navnet på ingrediensene på målspråket;

— øve på å beskrive hvordan man går fram for å lage matretten;

— lage og fremføre et rollespill på målspråket;

- lage veggplakater med matoppskriften både på norsk og målspråket, beskrive og illustrere matretten.

Lærerne tilrettelegger for at elevene kan være kreative og eksperimentere med språket når de skal skape dialogene til rollespillene og spille ut sine roller, blant annet ved at de har rekvisitter til disposisjon, som stekepanne, kokkelue m.m. Under selve matlagingen på skolekjøkkenet gjør elevene filmopptak av hverandre mens de forklarer på målspråket hvordan de går fram: De skal stille hverandre spørsmål og svar, og slik skapes tilnærmingsvis små, spontane dialoger, som -Emil, ¿̇qué haces? [Emil, hva gjør du?]; -Corto las patatas [jeg skreller potetene] [...], -echo el aceite [jeg heller i olje] og lignende. Ulike gjenstander og redskaper er altså med på å levendegjøre og konkretisere læringsinnholdet (jf. Skjelbred, 2019, s. 20; 22), og teoretisk kunnskap kobles til innlevelsesevne og uttrykkskraft (jf. Bjørnerud \& Nilsen, 2021, s. 70).

Opplegget avsluttes med et fellesmåltid for alle involverte elever og lærere. Elevene er ansvarlige for å dekke på bordene, servere maten og presentere hva de respektive matrettene består av (slik kelnere gjør). Informanten trekker fram som positive erfaringer fra denne type prosjekt at elevene ansvarliggjøres. De tenker, løser problemer og skaper produkter sammen. Dette er med 
på å skape og opprettholde et godt skolemiljø. Med andre ord, felleskapssentreringen inngår som en sentral komponent, der elevene får mulighet til å utvikle seg som hele mennesker (jf. Munthe, 2020, s. 230-231; Bjørnsrud \& Nilsen, 2021, s. 68).

Som nevnt innledningsvis, er et sentralt mål i fagfornyelsen (LK20) at tverrfagligheten skal styrkes (Kunnskapsdepartementet, 2017b, s. 5). Fem av informantene var opptatt av at fremmedspråksfaget ofte blir nedprioritert ved igangsetting av tverrfaglige prosjekter ved egen skole. De antydet som mulige årsaker timeplanmessige utfordringer, og at fremmedspråksfaget, særlig spansk, har lav status. Derfor ser man kanskje ikke hvilke verdier spansk/fremmedspråk kan tilføre tverrfaglige prosjekter, for eksempel innen historiske og samfunnsfaglige temaer. De håpet derfor at fagfornyelsen skal bidra til at spanskfaget blir mer inkludert. Hvilke faktorer som avgjør hvorvidt og på hvilke måter spansk/ fremmedspråk inkluderes i tverrfaglig arbeid i skolen er noe som bør undersøkes nærmere.

\section{Konklusjon}

Resultatene fra denne studien viser kun et lite utvalg av hvordan ungdomsskolelærere jobber med kulturspesifikke og allmenndannende temaer i spanskfaget. Når det gjelder valg av lærmidler legger intervjupersonene vekt på at elevene befinner seg på et nybegynnernivå i spansk, og at deres kjennskap til kultur og kulturelle manifestasjoner i spanskspråklige kontekster er varierende, og ofte svært begrenset. I arbeidet med å tilpasse undervisningen til elevenes læreforutsetninger inngår både læreboka, ulike digitale verktøy og medier og populærkulturelle uttrykksformer som sentrale komponenter. Resultatene tyder på at informantene, i større og eller mindre grad, forsøker å kombinere teoretiske og faktaorienterte tilnærminger til lærestoffet med mer affektive sider ved læringen, ved å inkludere elevenes tidligere kunnskaper og erfaringer, følelser, holdninger og engasjement, noe som er i tråd med gjeldende tendenser innen fremmedspråksundervisningen (jf. Risager, 2018). Informantene kom med en rekke eksempler på tilpassede og autentiske læremidler de bruker for å gi elevene ulike innfallsporter til kulturrelaterte temaer, særlig i tilknytning til dagliglivet (kultur med liten k). Resultatene antyder at valg av land og steder det settes fokuseres på i spansktimene, styres i stor grad av føringer i læreboka og lærernes førstehåndkunnskap om enkelte spansktalende land. 
Med hensyn til utvikling av elevenes demokratiforståelse og gjennomføring av tverrfaglige prosjekter, kom informantene med færre konkrete eksempler, men resultatene kan tyde på at elevmedvirkning og deltakerdimensjonen spiller en viktig rolle: Elevene skal oppleve hvordan det er å bidra på en positiv måte og bli ansvarliggjort i et læringsfelleskap. Dette er i tråd med Ulvik og Sæverot (2020, s. 42), som understreker at en stor del av danningsfremmende undervisning handler om "å lære å leve sammen".

Det trengs mer empirisk forskning rundt lærernes valg og bruk av læremidler i spanskfaget for å styrke elevenes kultur- og demokratiforståelse, ikke bare med henblikk på lærerperspektivet, men også elevperspektivet, og de ulike innholds- og diskursive aspektene ved læremidlene som benyttes.

\section{Referencer}

Adelmann, K. (2009). Konsten att lyssna. Didaktiskt lyssnande i skola och utbilding. Studentlitteratur.

Bjørnsrud, H. \& Nilsen, S. (2021). De uferdige utdanningsreformer og Fagfornyelsen (LK2O). Om det som var, det som er, og det som ennå ikke er til. Gyldendal Norsk Forlag.

Council of Europe. (2020). Common European Framework of Reference for Languages: Learning, Teaching, Assessment - Companion Volume. Council of Europe Publishing.

Creswell, J. W. \& Creswell, J. D. (2018). Research design: qualitative, quantiative, and mixed methods approaches (5. utgave). SAGE Publications.

Doetjes, G. (2018). Fransk, spansk og tysk i ungdomsskolen etter Kunnskapsløftet: styrket eller ikke? Nordic Journal of Modern Language Methodology, 6(2), 28-56. Lokalisert 14. januar 2021 på: https://doi.org/10.46364/njmlm.v6i2.513

Eide, L. (2012). Representasjoner av målspråkområdet i fremmedspråksfaget (doktoravhandling). Universitetet i Bergen.

Eide, L. (2013). Forestillinger om spanskfaget: et kritisk blikk på lærebøker i spansk. Acta Didactica, 7(1), 1-17. https://doi.org/10.5617/adno.1111

Fernández, S. S. (2019). Kritisk kulturel bevidsthed i spanskfaget. I: A. S. Gregersen (red.), Sprogfag i forandring - pcedagogik i praksis (s. 79-98). Samfundslitteratur.

Gamlem, S. M. \& Rogne, W. M. (2016). Lceringsprosesser - dybdeforståelse, danning og kompetanse. Gyldendal Akademisk.

Hansen, J. J. (2010). Lceremiddellandskabet: Fra loeremiddel til undervisning. Akademisk Forlag. 
Hansen, J. J. (2012a). Læremiddelbegrebet - en kategori i didaktikken. I: S. T. Graf, J. J. Hansen, T. I. Hansen (red.), Loeremidler i didaktikken - didaktikken i loeremidler (s. 15-40). Klim.

Hansen, J. J. (2012b). Mellem læremiddeldesign og didaktisk design. I: S. T. Graf, J. J. Hansen \& T. I. Hansen (red.), Loeremidler i didaktikken - didaktikken $i$ loeremidler (s. 41-58). Klim.

Hansen, T. I. \& Gissel, S. T. (2017). Quality of learning materials. IARTEM e-journal, 9. 122-141.

Heimark, G. (2013). Praktisk tilnoerming i teori og praksis. Ungdomsskolelcereres forståelse av en praktisk tilncerming ifremmedspråksundervisningen (doktorgradsavhandling). Universitetet i Oslo. Lokalisert den 14. januar 2021 på: http://urn.nb.no/URN:NBN:no-38743

Kirke-, utdannings- forskningsdepartementet. (1993). Loereplan for grunnskole, videregående opploering og voksenopploering. Generell del. Lokalisert den 25. april 2021 på: Den generelle delen av læreplanen - bokmål (udir.no)

Klafki, W. (2001). Kategorial dannelse. I: E. L. Dale (red.), Om utdanning. Klassiske tekster (s. 167-203). Gyldendal Norsk Forlag.

Krumsvik, R. J. (2019). Kvalitative metodar i lærarutdanninga. I: R. J. Krumsvik (red.), Kvalitativ metode i loerarutdanninga (s. 151-19o). Fagbokforlaget.

Kunnskapsdepartementet. (2017a). Overordnet del-verdier og prinsipper $i$ grunnopploeringen. Lokalisert den 20. desember 2020 på:

https://www.udir.no/laring-og-trivsel/lareplanverket/utgatt/generell-del-avlareplanen-utgatt/

Kunnskapsdepartementet. (2017b). Strategi for fagfornyelsen av Kunnskapsløftet og Kunnskapsløftet samisk. Kunnskapsdepartementet. Lokalisert den 6. januar 2021 på: strategi-for-fagfornyelsen2.pdf (regjeringen.no)

Kvale, S. \& Brinkmann, S. (2009). Det kvalitative orskningsintervju. Gyldendal Akademisk.

Lantolf, J.P. \& Poehner, M.E. (2014). Sociocultural Theory and the Pedagogical Imperative in L2 Education. Vygotskian Praxis and the Research/Practice Divide. Routledge.

Llovet Vilà, X. (2019). Læremidler i fremmedspråksfaget. I: C. Bjørke \& Å. Haukås (red.), Fremmedspråksdidaktikk (s. 304-323). Cappelen Damm Akademisk.

Merriam, S. \& Tisdell, E. S. (2016). Qualitative Research. A Guide to Design and Implementation. Jossey-Bass.

Munthe, E. (2020). Planlegging av undervisning. I: R. J. Krumsvik \& R. Säljö (red.), Praktisk-pedagogisk utdanning. En antologi (2. utgave) (s. 215-240). Fagbokforlaget.

Nasjonalt senter for engelsk og fremmedspråk i opplæringen. (2021). Elevane sitt val av framandspråk på ungdomsskulen 202O-21. Notat 01/2021. Lokalisert den 14. januar 2021 på: Microsoft Word - Elevane sine val av framandspråk i ungdomsskulen 20-21.docx (hiof.no)

von Oettingen, A. (2017). Almen didaktik eller kunsten at undervise. I: H. Sæverot \& T.C. Werler (red.), Pedagogikkens språk. Kunnskapsformer $i$ pedagogikkvitenskap (s. 192-212). Gyldendal Akademisk.

von Oettingen, A. (2018). Pædagogisk forskning mellem teori, empiri og prakis Bidrag til en empirisk dannelsesforskning. I: A. von Oettingen (red), Empirisk dannelsesforskning (s. 19-67). Hans Reitzels Forlag. 
Risager, K. (2018). Representations of the World in Language Textbooks. [E-bok]: https://doi.org/10.21832/RISAGE9559

Risager, K. \& Svarstad, L. (2020). Verdensborgeren og den interkulturelle loering. Inspiration og nytcenkning til sprogfagene og andre fag. Samfundslitteratur.

Sawyer, K. R. (2014). Introduction: The New Science of Learning. I: K. R. Sawyer (red.), The Cambrigde Handbook of Learning Sciences (s. 1-30) (2. utgave). Cambridge University Press.

Solfjeld, K. (2007). Andre fremmedspråk på ungdomstrinnet - med praktisk tilnærming. Rapport fra en intervjuundersøkelse. Fremmedspråksenteret. Fokus på språk. (1). Lokalisert den 14. januar 2021 på: Microsoft Word - FPS online_1_2007-BT.doc (hiof.no)

Soriano Ayala, E. (2013). Repensar los procesos de enseñanza-aprendizaje en la sociedad global e interconectada. I: E. Soriano Ayala (red.), Interculturalidad y Neocomunicación (s. 89-115). Editorial La Muralla.

St. Meld. nr. 28. (2016). Fag - Fordypning - Forståelse. En fornyelse av Kunnskapsløftet (St. Meld. 28 2015-2016). Lokalisert den 20. desember 2020 på: Meld. St. 28 (2015-2016) - regjeringen.no

Stray, J. H. (2011). Demokrati på timeplanen. Fagbokforlaget.

Tomlinson, B. (2012). Introduction: Textbooks and Materials Evaluation. I: M. Eisenmann \& T. Summer (red.), Basic Issues in EFL Teaching and Learning (s. 343355). Universitätsverlag Winter.

Ulvik, M. \& Sæverot, H. (2020). Pedagogisk danning. I: R. J. Krumsvik \& R. Säljö, Praktisk-pedagogisk Utdanning. En antologi (2. utgave). Fagbokforlaget.

Utdanningsdirektoratet. (2006). Læreplan i fremmedspråk (FSPo1-01). Lokalisert den 20. desember 2020 på: Læreplan i fremmedspråk (FSP1-o1) (udir.no)

Utdanningsdirektoratet. (2011). Det felles europeiske rammeverket for språk: Loring, undervisning, vurdering [The Common European Framework of Reference for Languages. Learning, teaching and assessment]. Lokalisert den 6. januar 2021 på: det-felles-europeiske-rammeverket-for-sprak-2011.pdf (udir.no)

Utdanningsdirektoratet. (2019). Loereplan i fremmedspråk (FSP-O1-02). Lokalisert den 20. desember 2020 på: Læreplan i fremmedspråk (FSPo1-02) (udir.no)

Utdannings- og forskningsdepartementet. (2005). Loreplaner for gjennomgående fag i grunnskolen og videregående opploering. Loreplaner for grunnskolen (824,8610659). Utdanningsdirektoratet.

Wolvin, A. \& Coakley, C. G. (1996). Listening (5. utgave). McGraw Hill.

\section{Lærebøker som det henvises til i artikkelen}

Børve, M. L., Fjerdingren, A. M., Hernández, G. M., Manjón, O. S. \& Sveia-Nilsen, S. (2018). Gente 8. Aschehoug Undervisning.

Børve, M. L., Fjerdingren, A. M., Hernández, G. M., Manjón, O. S. \& Sveia-Nilsen, S. (2019a). Gente 9. Aschehoug Undervisning.

Børve, M. L., Fjerdingren, A. M., Hernández, G. M., Manjón, O. S. \& Sveia-Nilsen, S. (2019b). Gente 10. Aschehoug Undervisning. 
Cleaverley, K., Dybwad, A., Ferragut, C. \& Palomino, M. A. (2005a). Chicos Chicas 1. Spansk for ungdomstrinnet: Elevbok. Aschehoug Undervisning.

Cleaverley, K., Dybwad, A., Ferragut, C. \& Palomino, M. A. (2005b). Chicos Chicas 2. Spansk for ungdomstrinnet: Elevbok. Aschehoug Undervisning.

Cleaverley, K., Dybwad, A., Ferragut, C. \& Palomino, M. A. (2006). Chicos Chicas 3. Spansk for ungdomstrinnet: Elevbok. Aschehoug Undervisning.

Hanson, Ö., \& Teva, I. M. (2006). ; Vale! 1. Tekstbok. Cappelen Forlag.

Hanson, Ö., \& Teva, I. M. (2007). ¡Vale! 2. Tekstbok. Cappelen Forlag.

Hanson, Ö., Teva, I. M. \& Klingenberg, D. (2008). ¡ Vale! 3. Tekstbok. Cappelen Forlag. Riquelme, A. O., Salomonsen, L., Knutagård, M. S., de la Motte, A., Lizana, H. (2004). Amigos tres, textos. Gyldendal Forlag.

Riquelme, A. O., Salomonsen, L., Knutagård, M. S., de la Motte, A., Lizana, H. (2005). Amigos dos, textos. Gyldendal Forlag.

Riquelme, A. O., Salomonsen, L., Knutagård, M. S., de la Motte, A., Lizana, H. (2006). Amigos tres, textos. Gyldendal Forlag. 